\title{
Comparative Anatomy and Histology of Black Pomfret (Formio niger) and Nile tilapia (Oreochromis niloticus) Kidney
}

\author{
Nurul Safitri Apriliani ${ }^{1}$, Muhammad Jafar Luthfi ${ }^{2}$ \\ ${ }^{1}$ Center for Integrative Zoology; ${ }^{2}$ Biological Education Department, Faculty of Science and Technology, UIN Sunan Kalijaga \\ Jl. Marsda Adisucipto 55281 Yogyakarta, Indonesia \\ Author correspondency: \\ nurulsafitri89@gmail.com ${ }^{1}$
}

\begin{abstract}
Black pomfret and nile tilapia are belonging to order Perciformes. Both fish are live in different habitat. Black pomfret is marine water whereas nile tilapia is in freshwater. The purpose of the study was to determine anatomy and histology of the kidneys structures in both fishes. Histological preparations were done using paraffin method, with Hematoxylin-Eosin (HE) staining. The results, showed that Black pomfret and nile tilapia have y-shape kidney. Nile tilapia has darker red colour and softer texture than black pomfret kidney. Histologically, black pomfret and nile tilapia kidneys have a distal tubule, proximal tubule, glomerulus and lymphoid tissue. Glomerular diameter of nile tilapia $(69,22 \mu \mathrm{m})$ was larger than pomfret $(61,25 \mu \mathrm{m})$. It can be concluded that differences between anatomical and histological structure of kidney are affected by habitat differences.
\end{abstract}

Keywords: anatomy; black pomfret (Formio niger); histology; kidney; nile tilapia (Oreochromis niloticus).

\section{INTRODUCTION}

Fishes (pisces) are members of subphylum vertebrates that have species number more than 27,000 species in the world. Fish has the most diversity in terms of morphology (Bond, 1979). There are also anatomical and histological variations which is manifest in its form and function. This could be caused by different habitats, even in fish in the same order, such as black pomfret (Formio niger) and nile tilapia (Oreochromis niloticus).

Black pomfret and nile tilapia are belonging to the order Perciformes. These fish live in different habitats. black pomfret (Formio niger) is one of many fishes species found in marine areas in Indonesia, especially in the southern sea. Nile tilapia is a freshwater fish. It can be found in lakes, river, and water reservoirs (Suyanto, 1994; Djarijah, 1995; Taufik et al., 2002). Osmoregulation is the capacity of aquatic animals to control the water and ion balance between the body and its environment, or a process of osmoregulation (Nicol, 1967; Fujaya, 2004). The organ that has an important role in osmoregulation process in the body is kidney (Karl, 1962). Kidney is an excretory organ that has an important role in the filtration and excretion process. The fish of kidney absorb some salt and release the salt into the bloodstream. The fish kidney also has a pump that will take salt from water and release ammonia and other waste products (Karl, 1962).

The function of each parts of the kidneys that involved in the osmoregulation process will show some differences between the renal fish structure that living in marine or freshwater. Comparative anatomical study was conducted to determine the differences anatomical and histological renal organ of black pomfret and tilapia in the same order level. The comparisons including the different in histological and anatomical structures of renal fish organ that may affected by the physiological factors of the fishes due to habitat difference.

\section{MATERIALS AND METHODS}

In this study, we used three adults black pomfret (Formio niger), obtained from Pangandaran Beach, West Java and three adults nile tilapia (Oreochromis niloticus) from Nila Cultivation Center, Cangkringan Yogyakarta.

Anatomical observation were done by observing the topography, colour, texture, shape and length of the kidney. Histological observation were done on histological slides stained with using Hematoxylin-Eosin (HE). Histological slides were made using paraffin method.

\section{RESULTS AND DISCUSSION}

Black pomfret (Formio niger) and nile tilapia (Oreochromis niloticus) (Figure 1 \& Figure 2) have similarities as common perciformes fish, which have dorsal, caudal, anal, pelvic and pectoral fins. Dorsal fin of nile tilapia has a spiny fin or a hard fin called spinal fin. Pomfret and tilapia have difference in its caudal fin shape. Pomfret has a fork-shaped, whereas tilapia fish 
caudal fin is rounded shaped. Mouth of pomfret has a terminal type, whereas in tilapia fish is sub-terminal and tapered shaped. Pomfret body is slim, with the dorsal and ventral body is strong and equally convex, whereas tilapia body is flat-shaped toward the vertical (compressed). Scales on both fish also have differences. Black pomfret has small size, tight scales covering the dorsal and ventral parts of the body, whereas tilapia has large, rough and well-scales (Kottelat et al., 1993).

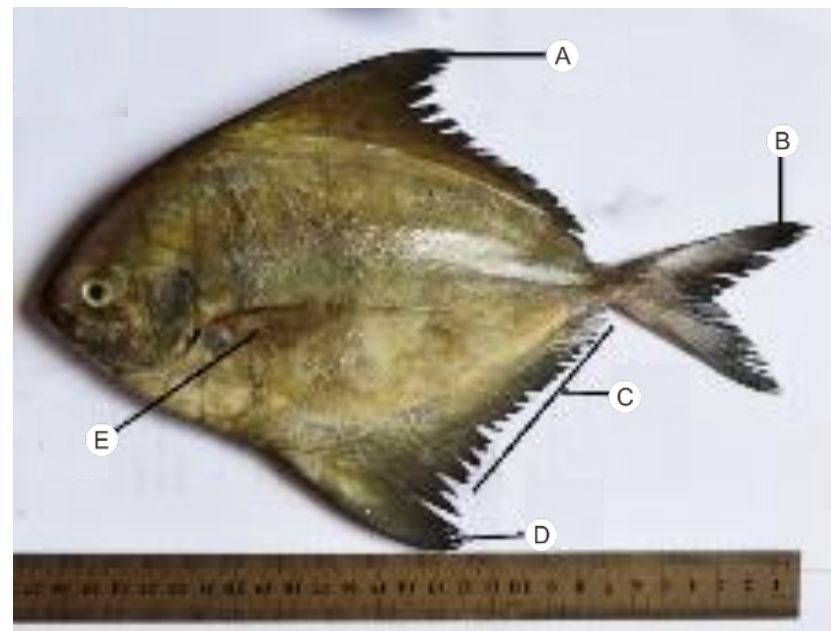

Figure 1. Morphology of black pomfret (Formio niger). (A). Dorsal; (B). Caudal; (C). Anal; (D). Pelvic; (E). Pectoral.

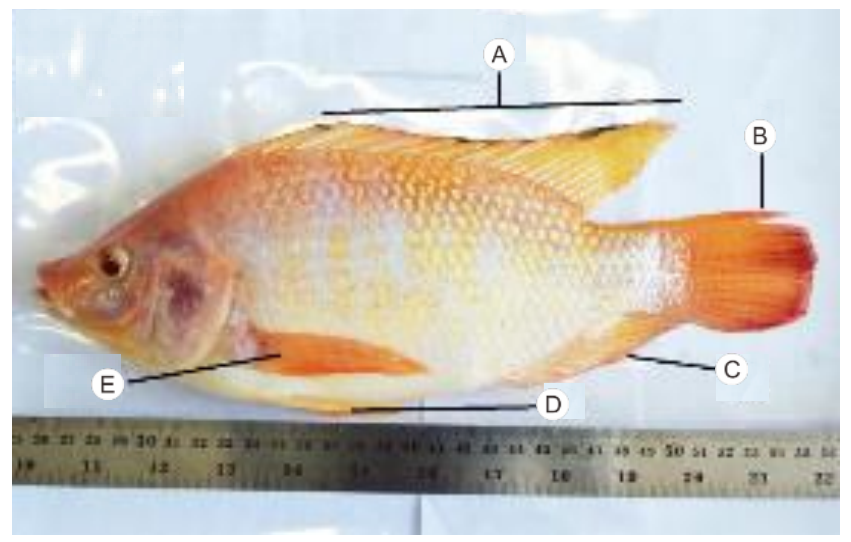

Figure 2. Morphology of nile tilapia (Oreochromis niloticus). (A). Dorsal; (B). Caudal; (C). Anal; (D). Pelvic; (E). Pectoral.

\section{Kidney Anatomy of adult black pomfret (Formio} niger) and nile tilapia (Oreochromis niloticus)

Kidney of the pomfret has a longitudinal shape along the abdominal cavity (Figure 3). Similar to Lamprey, marine kidney generally elongated along the underside of vertebrae (spine) and slightly lobuled (Karl, 1962; Ferguson, 1989 in Damayanti, 2010). In pomfret and tilapia fish the kidney and reproductive organ are located adjacent to the top of the celoem, and are divided into two specific system aisles (Kent, 1987).

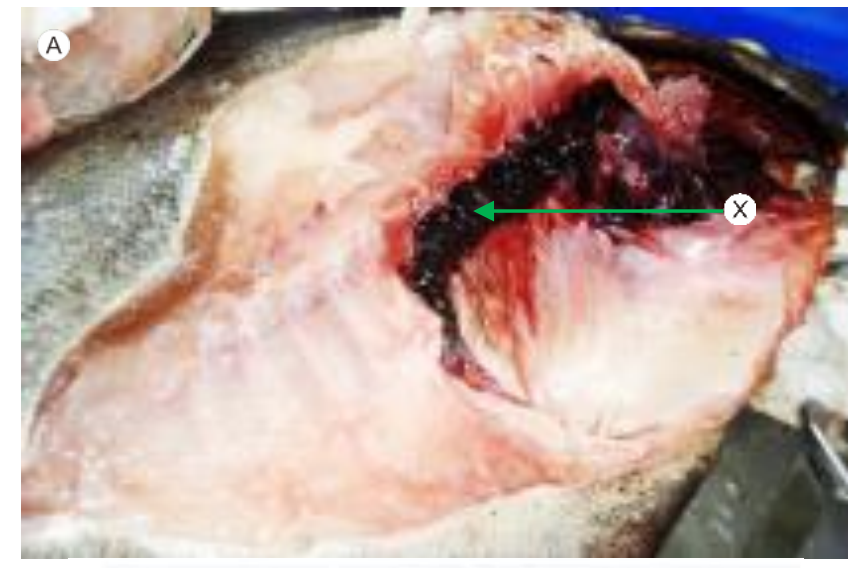

B

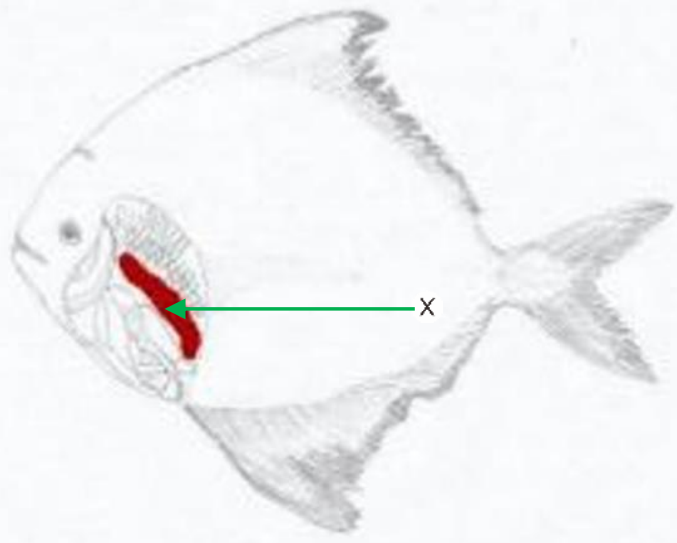

Figure 3. Topography of black pomfret (Formio niger) kidney. (X). Kidney, (A). Original topography of pomfret kidney, (B). Sketch topography of pomfret kidney.
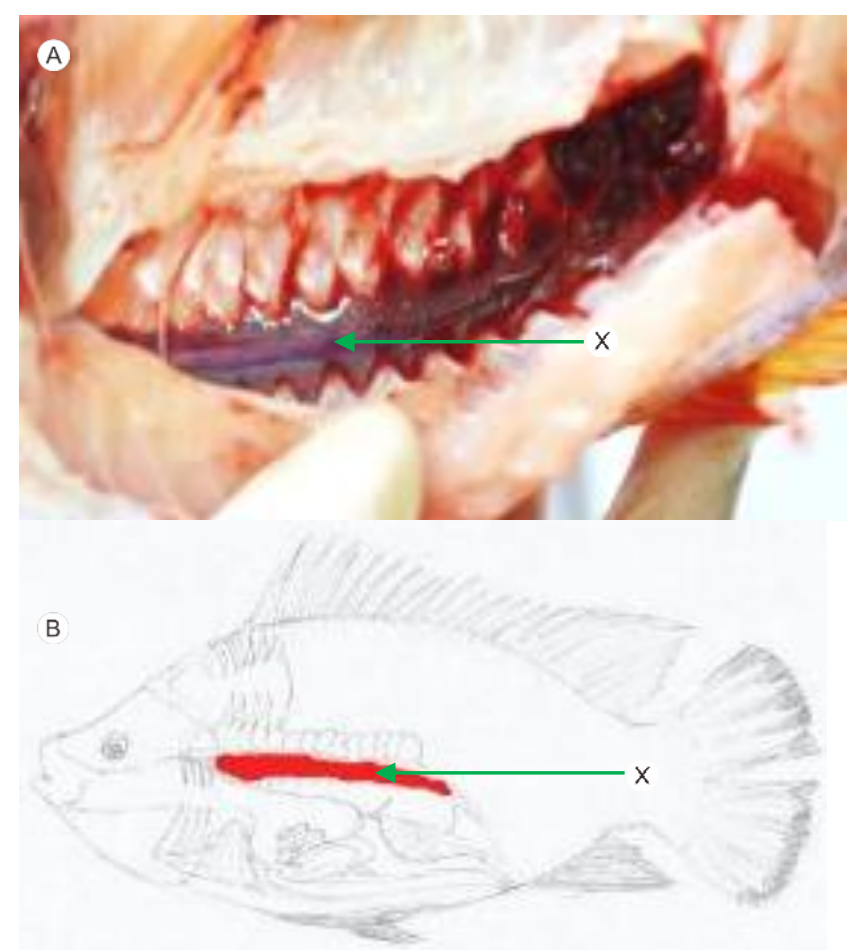

Figure 4. Topography of tilapia (Oreochromis niloticus) kidney. (X) Kidney, (A). Original topography tilapia kidney, (B). Sketch topography of tilapia kidney. 
The result of the research showed that kidney black pomfret and nile tilapia have a similarity to kidney of perciformes fish in general, which is $Y$-shaped form. Fish kidneys generally have different shapes to each

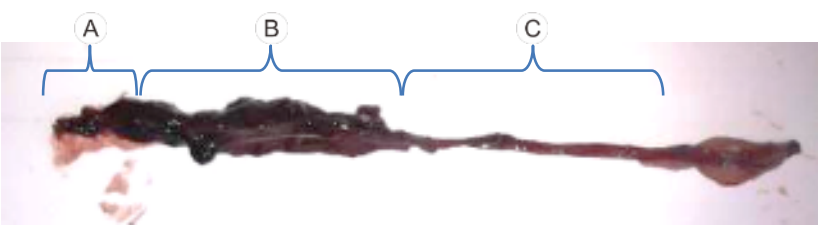

Figure 5. Anatomy of adult black pomfret (Formio niger) kidney, elongated shape and dark red colour. (A). Head kidney (Anterior); (B). Body kidney (Transition); (C). Tail kidney (Posterior).

Black pomfret kidney has a deep red color and has a soft kidney texture (Karl, 1962). Meanwhile, the tilapia kidney has a slightly softer texture than the pomfret's kidney, and has bright red-colored, compared to darker pomfret kidney. The differences in color and texture of the kidney are affected by pigment, number of capillary and connective tissue.

\section{Histology of adult black pomfret (Formio niger) and nile tilapia (Oreochromis niloticus) kidney}

Fish kidney has histological structure like the other marine vertebrate kidney, which have glomerulus and tubules (Fujaya, 2004). Glomerulus plays an important role in the process of excretion. The magnitude of the diameter of the glomerulus and the density of the tubules is related to filtration and filter blood. Based on the results of the study, there is a difference between the glomerular diameter of pomfret and tilapia fish.

The histology of pomfret and tilapia kidney is presented in Figure 7 and Figure 8.

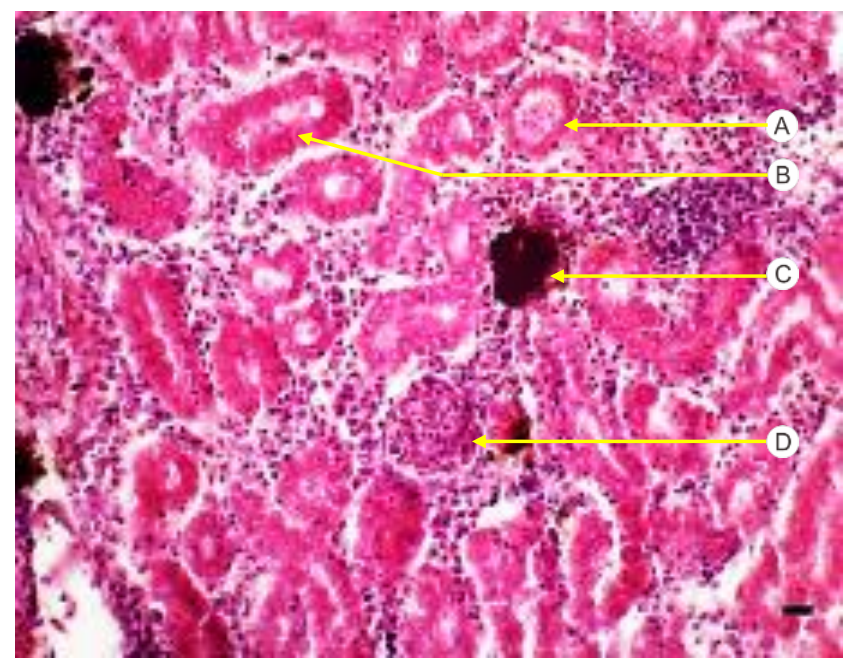

Figure 7. Histology of kidney of black pomfret (Formio niger). (A). Distal Tubule; (B). Proximal tubule; (C). Lymphoid tissue; (D). Glomerulus. HE staining. (40x10 magnification). class. Type of kidney and pomfret's configuration kidney is included in the same type of Yellow-tail fish, namely $y$-shape.

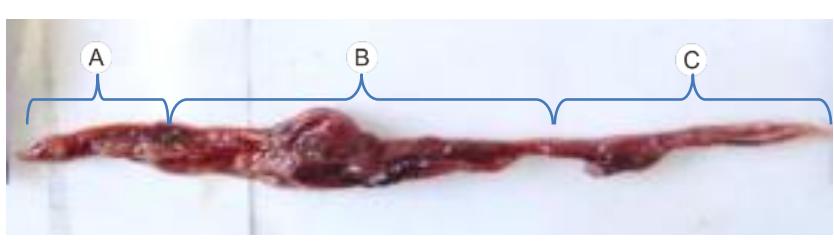

Figure 6. Anatomy of adult Nile tilapia (Oreochromis niloticus) kidney, elongated and bright red colour. (A). Head kidney (Anterior); (B). Body kidney (Transition); (C). Tail kidney (Posterior).

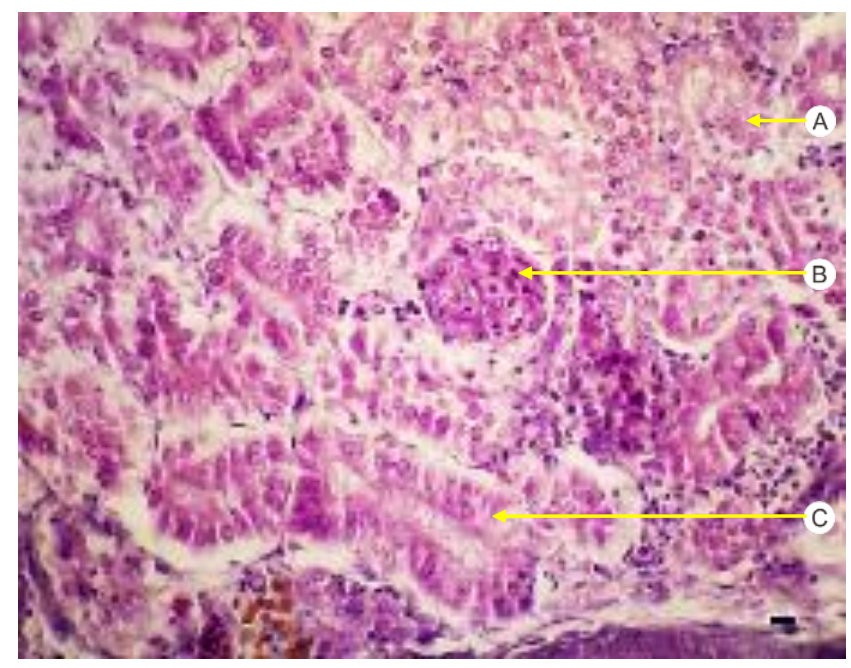

Figure 8. Histology of kidney of nile tilapia (Oreochromis niloticus). (A). Distal Tubule; (B). Glomerulus; (C). Proximal tubule. HE staining. (40x10 magnification).

Based on histological observations on serial preparations, adult black pomfret (Formio niger) kidney has smaller glomerular diameter $(61.25 \mu \mathrm{m})$ compared to adult tilapia $(69.22 \mu \mathrm{m})$. This finding is consistent with Marshall \& Smith (1930), which stated that fish living in water with low salinity content having a larger glomerular size than fish living with water with high salinity. Karl (1962), also stated that freshwater fish kidney have more glomeruli than fish.

Based on the result it can be concluded that there is similar kidney anatomy yet different size of glomerular diameter in pomfret and tilapia. This is an adaptive character due to different environmental factors. Regarding to the way of osmoregulation process, different habitats greatly affect the structure and function of the kidney (Margaret, 1957; Karl, 1962). 


\section{CONCLUSION}

Based on the result of research, we drew conclusion as follows:

1. Pomfret and tilapia have the same anatomical kidney structure, consisting of head, body and tail of the kidney. But the tail/posterior kidney pomfret is longer than the body part (transition). The location of the same kidney that is attached to ventral part of vertebrae, but different in the direction of the posterior part of the kidney. The color and texture of the kidneys are different. Relatively softer on tilapia than pomfret. The kidneys of tilapia fish have a bright red-red color, while the pomfret's kidney has dark red color. In terms of morphometry, the weight and length of the kidney are relatively larger in tilapia.

2. Pomfret and tilapia have the same histological structure of the kidney, which consists of distal tubules, proximal tubules, and glomeruli and lymphoid tissue, but different in glomerular diameter.

\section{REFERENCES}

Bond, C.E. 1979. Biology of Fishes. Philadelphia: W. B. Saunders Company.

Damayanti, F. N. 2010. Pengaruh Pencemaran Logam Berat terhadap Kondisi Histologi Ikan Nila (Oreocromis niloticus Linn) dalam Karamba Jaring Apung di Blok Jangari Waduk Cirata. Thesis. Universitas Padjajaran, Jatinangor.
Djarijah, A. S. 1995. Nila Merah: Pembenihan dan Pembesaran secara Intensif. Kanisius, Yogyakarta.

Ferguson, Hugh. 1989. Systematic Pathology of Fish, A Test and Atlas of Comparative Tissue Responses in Diseases of Teleosts. Iowa State Univ. Press. Ames, Iowa.

Fujaya, Yushita. 2004. Fisiologi Ikan Dasar Pengembangan Teknik Perikanan. Jakarta: PT Rineka Cipta.

Karl L. 1962. Ichtyology. John Wiley \& Sons. Inc: New York.

Kent G. C. 1987. Comparative Anatomy of the VERTEBRATES. $6^{\text {th }} \mathrm{ed}$. Times Mirror/Mosby Toronto: College Publishing.

Kottelat M, Whitten AJ, Kartikasari SN, Wirjoatmojo S. 1993. Freshwater fishes of Western Indonesia and Sulawesi. Hong Kong: Periplus Editions. Hlm: 344

Margaret E. B. 1957. The Physiology of Fishes: Behavior. New York: Academic Press Inc, Publisher.

Nicol, J.A.C, 1967. The biology of marine animals. $2^{\text {nd }} e d$. New York: Wiley-Interscience.

Suyanto. 1994. Nila. Jakarta: Penebar Swadaya.

Taufik, I., S. Koesoemadinata, Sutrisno, \& Nugroho. 2002. Potensi Akumulasi Insektisida Klorpiricosetil dalam Jaringan Tubuh Ikan Nila (Oreochromis niloticus). Jurnal Penelitian Perikanan Indonesia, 8 (3): 37-44. 